\title{
Analytical Determination of Benzophenone-3 in Sunscreen Preparations Using Boron-Doped Diamond Electrodes
}

\author{
Michelli Thomaz Laranjeira ${ }^{1}$, Fabio de Lima ${ }^{1}$, Silvio Cesar de Oliveira ${ }^{1}$, Valdir Souza Ferreira ${ }^{1}$, \\ Robson Tadeu Soares de Oliveira ${ }^{* 2}$ \\ ${ }^{1}$ Departamento de Química, Universidade Federal de Mato Grosso do Sul, Campo Grande, Brazil \\ ${ }^{2}$ Instituto de Ciências Biológicas e Naturais-ICBN, Universidade Federal do Triângulo Mineiro, Uberaba, Brazil \\ E-mail: rtsoj2003@yahoo.com.br \\ Received October 17, 2010; revised November 17, 2010; accepted May 1, 2011
}

\begin{abstract}
Abstrac
A new electroanalytical procedure was developed for the determination of Benzophenone-3 (BENZO) in commercial sunscreen as the active ingredient. The procedure is based on the use of electrochemical methods as cyclic and square-wave voltammetry, with boron-doped diamond (BDD) electrodes. The reduction of BENZO in Britton-Robinson buffer $\left(0.1 \mathrm{~mol} \cdot \mathrm{L}^{-1}\right)$ using this type of electrode gives rise to one irreversible peak in $-1.30 \mathrm{~V}$ (versus $\mathrm{Ag} / \mathrm{AgCl}$ ) in presence of cationic surfactant cetyltrimethylammonium bromide $(\mathrm{CTABr})$. The proposed electrochemical method was successfully applied to the analysis of commercially available pharmaceutical preparations.
\end{abstract}

Keywords: Boron-Doped Diamond, Benzophenone-3 BENZO and Square-Wave Voltammetry

\section{Introduction}

Benzophenone-3 (BENZO) (Figure 1) is the organic compound widely used in sunscreen agent that absorbs and dissipates ultraviolet radiation or in a variety of cos metic products [1]. BENZO also has been used as ultra violet stabilizer in plastic surface coatings for food packaging to prevent polymer or food photodegradation [2] and is approved by the U.S. Food and Drug Adminstration as an indirect food additive.

The focus of pharmaceuticals and ingredients in personal care products, including organic sunscreen agents, as environmental pollutants is increasing because these compounds may enter the aquatic environment not primarily as a result of manufacturing practices, but from<smiles>COc1ccc(C(=O)c2ccccc2)c(O)c1</smiles>

Figure 1. Chemical structure of benzophenone-3.

their steady and widespread use in human and veterinary daily activities [3]. Furthermore, little is known about the potential hazards associated with recurring human or ecologic exposures to these synthetic substances, many of which are bioactive. BENZO, one of these substances, has been detected in surface waters [4], drinking water, and wastewater [5]. The development of methods capable of directly quantifying BENZO in commercial pharmaceutical preparations also becomes important in quality control of sunscreens.

The most often techniques observed in the literature for the determination sunscreen composition are highperformance liquid chromatography (HPLC) [6,7] and gas chromatography (GC) coupled with various detection methods such as ultraviolet (UV) [8] and mass spectrometry [9]. However, electrochemical techniques are useful alternative methods widely used in pharmaceutical applications. They are usually easy and rapid to perform and are less expensive than chromatographic methods. In addition, the sensitivity of electrochemical methods is often greater than that of spectrophotometric procedures.

A few studies have reported the use of electroanalytical methods to determine BENZO and related compounds. Vidal, et al. [10] applied chemically surfacemodified carbon nanoparticles for the extraction and electrochemical determination of phenolic impurities such as BENZO (2-hydroxy-4-methoxybenzophenone). 
The hydrophilic carbon nanoparticles were readily suspended and separated by centrifugation prior to deposition onto suitable electrode surfaces and voltammetric analysis. Voltammetric peaks provide concentration information over a $10-100 \mu \mathrm{M}$ range and an estimated limit of detection of ca. $10 \mu \mathrm{M}$ (or $2.3 \mathrm{ppm}$ ) for BENZO. Alternatively, analyte-free carbon nanoparticles immobilized at a graphite or glassy carbon electrode surface and directly immersed in analyte solution bind BENZO with an estimated Langmuir binding constants of $K \approx 6000$ $\mathrm{mol} \cdot \mathrm{L}^{-1}$ at $\mathrm{pH} 9.5$ and it also give characteristic voltammetric cathodic response for BENZO with a linear range of ca. $1-120 \mu \mathrm{M}$. The estimated limit of detection is improved to ca. $5 \mu \mathrm{M}$ (or $1.2 \mathrm{ppm}$ ) for BENZO.

Razak, et al. [10] reported the use of differential pulse polarographic method for detection and trace determination of benzophenone (the main impurity) in phenytoin powder. The method depends upon the polarographic activity of benzophenone in Britton-Robinson buffer $\mathrm{pH}$ 5.6. The limit of detection was found to be $2.5 \times 10^{-6}$ $\mu \mathrm{g} \cdot \mathrm{mL}^{-1}$. Phenytoin has been analysed polarographically after oxidation with alkaline permanganate to give benzophenone; the limit of detection was found to be $6 \times$ $10^{-6} \mu \mathrm{g} \cdot \mathrm{mL}^{-1}$. In a study performed by Cardoso, et al. [12], was proposed a methodology based on electrochemical reduction for the simultaneous determination of three sunscreen agents, namely 4-methylbenzylidene camphor (MBC), BENZO and 2-ethylhexyl-4-methoxycinnamate (EHMC) by differential-pulse polarography (DPP). The highest peak currents and optimal separation of reduction peaks were obtained by using a supporting electrolyte consisted of Britton-Robinson buffer-methanol (8:2) solution at $\mathrm{pH} 4.0$ and cationic surfactant $3.0 \times$ $10^{-4} \mathrm{~mol} \cdot \mathrm{L}^{-1}$ cetyltrimethylammonium bromide (CTABr). The methodology was validated using four commercial sunscreen preparations as a sample and the results sh- owed high recovery rates. The efficiency of the proposed methodology was demonstrated by comparing the results obtained by DPP with those obtained by the highperformance liquid chromatography (HPLC) method.

The procedures in electroanalysis strongly depend on working-electrode materials, increasing the interest in the development of new electrode materials. Carbon materials such as pyrolytic graphite, glassy carbon, and boron-doped diamond (BDD) have been widely used for electrochemical applications [13-17]. It is well established that BDD electrodes have several advantages compared with other carbon surfaces. BDD electrodes have been extensively studied in recent years, both for their fundamental electrochemical properties [18-21] and its various applications [22,23].

The outstanding electrochemical features of this mate- rial, including a wide potential window in aqueous solutions $[24,25]$, very low background current [26], weak adsorption for most types of organic molecules [27], high stability of response [28,29], and good electroactivity toward certain organic species all of which deactivate the surface of other conventional electrodes [30,31]—make this new material promising for electroanalytical applications [32-37], electrosynthesis [38,39], and electrochemical combustion [40-43], as well as for use as a supporting material in electrocatalysis [44-46]. Recent studies reported in the literature have shown that several inorganic, organic and biomolecules can be satisfactorily determined with the use of BDD electrodes [32,47-49].

The combination of square-wave voltammetry (SWV) and BDD electrodes has proved to be an interesting and desirable alternative for the analytical determination of some organic molecules $[49,50]$. So, in view of the lack of a simple and direct electroanalytical method for the determination of BENZO, the purpose of this investigation is the development of an electrochemical method capable of directly quantifying BENZO in commercial pharmaceutical preparations available in sunscreen form, using cyclic voltammetry and SWV with BDD as the working electrode.

\section{Experimental}

The stock solution of BENZO (Merck 99\%) was prepared by direct weighing in order to obtain a solution 1.0 $\times 10^{-3} \mathrm{~mol} \cdot \mathrm{L}^{-1}$ dissolved in methanol, followed by a dilution to a concentration of $1.0 \times 10^{-4} \mathrm{~mol} \cdot \mathrm{L}^{-1}$. The cationic cetyltrimethylammonium bromide (CTABr) (Acros, New Jersey, USA) surfactant was prepared to a concentration of $1 \%(\mathrm{~m} / \mathrm{V})$. The supporting electrolyte was pre- pared by dissolution of boric acid followed by dilution with acetic acid and phosphoric acid (all from Merck, Darmstadt, Germany) to a concentration of 0.04 $\mathrm{mol} \cdot \mathrm{L}^{-1}$. The solutions had their $\mathrm{pH}$ adjusted by sodium hydroxide solution (Merck, Darmstadt, Germany). All reagents were of analytical grade. The deionized water was puri- fied with a Milli-Q plus system (Millipore, Bedford, MA, USA). The samples were prepared by direct weighing in a $15 \mathrm{~mL}$ beaker, followed by solubilization in $10 \mathrm{~mL}$ of methanol with sonication for $5 \mathrm{~min}$. This solution was quantitatively transferred to a $25 \mathrm{~mL}$ volumetric flask and methanol was added to the mark. The use of methanol in the supporting electrolyte was necessary due to the low solubility of the sunscreen agents in aqueous medium.

The BDD electrodes were prepared in the Centre Suisse d'Electronique et de Microtechnique SA (CSEM), Neuchâtel, Switzerland, using the hot filament chemical vapor deposition (HF-CVD) technique with filament 
temperatures in the range of $2440^{\circ} \mathrm{C}-2560^{\circ} \mathrm{C}$ and a gaseous mixture containing methane, $\mathrm{H}_{2}$, and trimethylboron, with a final boron content of the order of $800 \mathrm{ppm}$.

The electrochemical experiments were carried out in a single-body Pyrex ${ }^{\circledR}$ glass cell provided with three electrodes and degassing facilities for $\mathrm{N}_{2}$ bubbling. The BDD electrode was glued onto a copper plate using a silver paste as previously reported in the literature [49,50]. The copper plate and the BDD edges were later isolated with Araldite ${ }^{\circledR}$ resin, leaving an exposed area of $0.025 \mathrm{~cm}^{2}$.

The reference electrode used was $\mathrm{Ag} / \mathrm{AgCl}$, where the all potentials are referred to this electrode. The auxiliary electrode was a $2.0 \mathrm{~cm}^{2} \cdot \mathrm{Pt}$ foil. The electrochemical experiments were also performed using a Model 283 EG\& G PARC electrochemical instrument controlled by a personal micro computer through the EG\&G Princeton Applied Research model 270 Research Electrochemistry Software. All solutions were deoxygenated by bubbling $\mathrm{N}_{2}$ for 10 min prior to measurements and the solutions were blanketed with the gas during measurements.

Analytical curves were obtained by means of spiking the supporting electrolyte. The measurements were performed without pre-treatment of the solutions, but $\mathrm{pH}$ was appropriately adjusted to the desired value.

\section{Results and Discussion}

\subsection{Electrochemical Behavior}

A cathodic polarization was necessary for conditioning the BDD surface prior to electroanalytical determinations. Such pre-treatment improves the voltammetric response of BDD surfaces, resulting in very low quantification limits and high data reproducibility [20]. Salazar-Banda, et al. [21] observed that after cathodic pre-treatments BDD electrodes exhibit dynamic electrochemical behav- ior-i.e., a progressive decrease in the electron transfer rate for the $\mathrm{Fe}(\mathrm{CN})_{6}{ }^{4-13-}$ redox couple as a function of time. This behavior has to be associated with a loss of superficial hydrogen due to oxidation by oxygen from the air. These results stress the need for performing ca- thodic pre-treatment just before the electrochemical ex- periments are conducted, in order to ensure reliable and reproducible results. In the literature there are several papers that used BDD electrode cathodically pretreated for electroanalytical applications [45,46,49-51]. Thus, before each analysis the BDD electrodes were pre-treated at $+3.2 \mathrm{~V}$, in order to oxidize possible adsorbed species on the electrode surface, and after at $-2.8 \mathrm{~V}$ (vs. $\mathrm{Ag} / \mathrm{AgCl}), 30 \mathrm{~s}$ each, in $\mathrm{HClO}_{4}$ solution $\left(0.1 \mathrm{~mol} \cdot \mathrm{L}^{-1}\right)$.

In this investigation, cyclic (CV) and square wave voltammetry (SWV) were utilized as electroanalytical tools for BENZO determination in aqueous solutions using sunscreen such as amount (commercial pharmaceutical preparations). Initially the cyclic voltammetric experiments were conducted using a standard solution of BENZO $\left(2.0 \times 10^{-4} \mathrm{~mol} \cdot \mathrm{L}^{-1}\right)$ in Britton-Robinson buffer solution ( $\mathrm{pH} \mathrm{6).} \mathrm{The} \mathrm{voltammetric} \mathrm{profile} \mathrm{of} \mathrm{currents}$ shown in Figure 2 reveals a peak related to reduction of BENZO on the BDD electrode in presence of cationic surfactant cetyltrimethylammonium bromide $(1.0 \%$ $\mathrm{m} / \mathrm{V})$.

It can be observed (Figure 2) the presence of a welldefined irreversible peak in the presence of surfactant (CTABr) cationic BENZO reduction in BDD, as well a

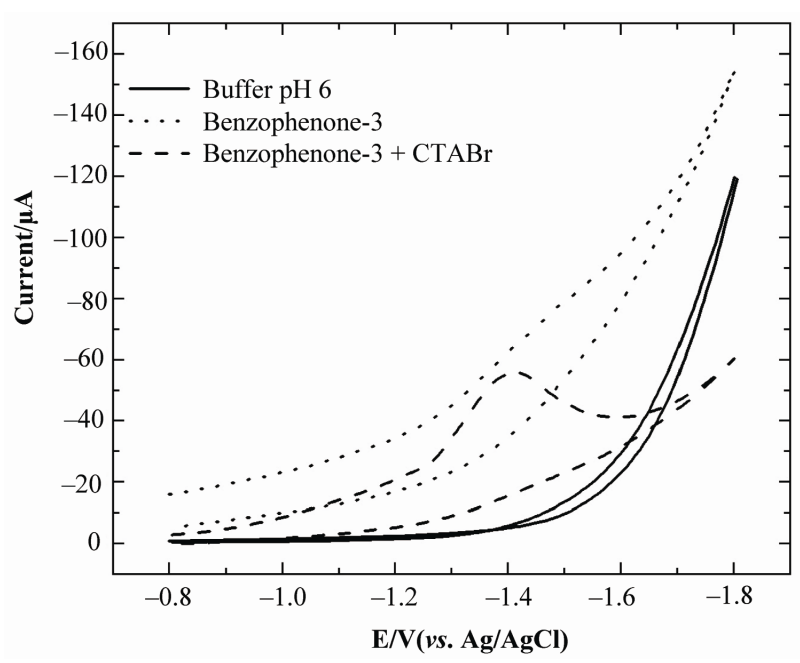

Figure 2. Cyclic voltammogram obtained in media of B-R buffer solution (pH 6) on a BBD electrode (solid line) and for benzophenone-3 $\left(2.0 \times 10^{-4} \mathrm{~mol} \cdot \mathrm{L}^{-1}\right)$ in presence (dashed line) and absence (doted line) of CTABr $(1.0 \% \mathrm{~m} / \mathrm{v})$ on a BDD electrode at $0.1 \mathrm{~V} \cdot \mathrm{s}^{-1}$.

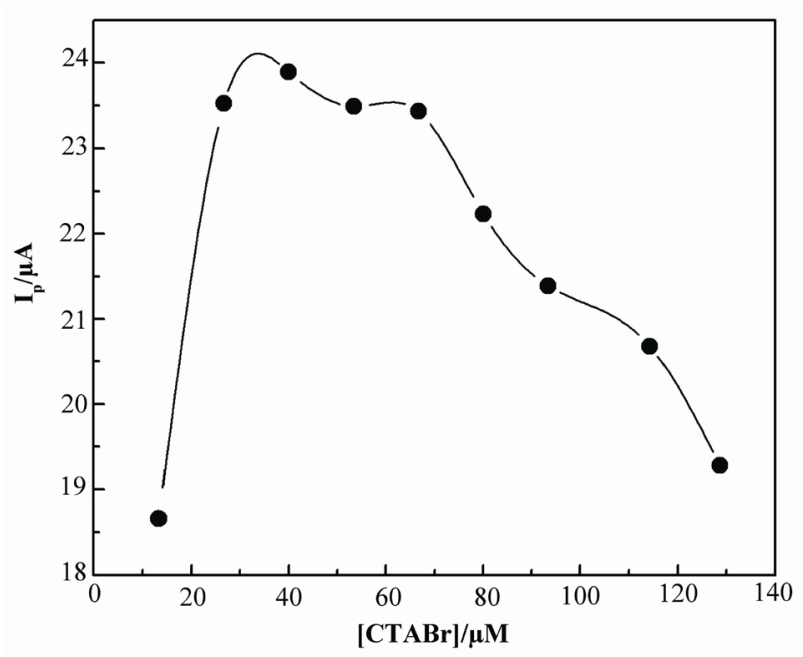

Figure 3. Dependence of the current peak of benzophenone-3 $\left(1.0 \times 10^{-4} \mathrm{~mol} \cdot \mathrm{L}^{-1}\right)$ on the CTABr concentration in 
Britton-Robinson buffer solution (pH 6), Scan rate $0.1 \mathrm{~V} \cdot \mathrm{s}^{-1}$. shift in peak potential for considerably less negative value and thus away from discharge potential of electrolyte. The influence of concentration on CTABr BENZO reduction in BDD was investigated (Figure 3). However, the BENZO reduction response on BDD was studied in presence of CTABr in range of $1.30 \times 10^{-5}$ until $1.43 \times$ $10^{-4} \mathrm{~mol} \cdot \mathrm{L}^{-1}$ using as electrolyte B-R buffer solution (pH6). The best results with respect to enhancement and shape of the peak current were obtained with $4.0 \times 10^{-5}$ $\mathrm{mol} \cdot \mathrm{L}^{-1}$ of $\mathrm{CTABr}$.

Meanwhile, the influence of $\mathrm{pH}$ of supporting electro-

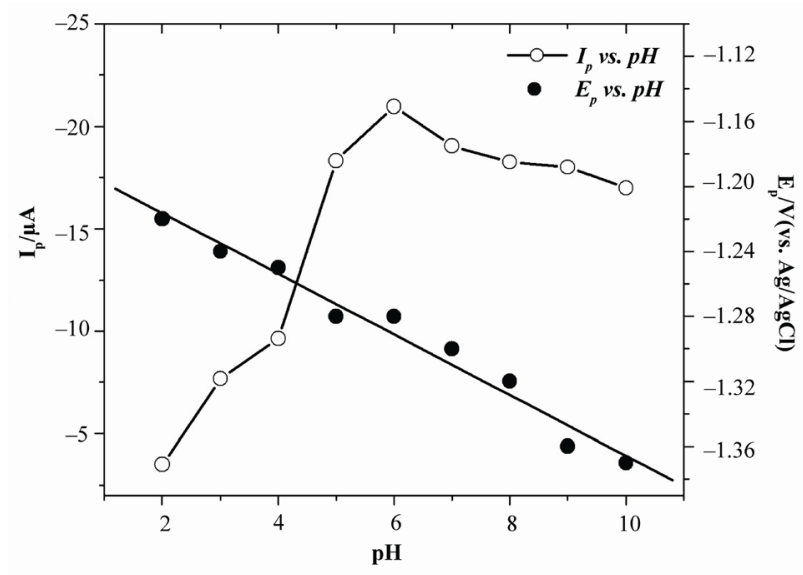

Figure 4. Influence of $\mathrm{pH}$ on peak current and peak potentials for cyclic voltammetry on a BDD electrode for benzophenone-3 $\left(1.0 \times 10^{-4} \mathrm{~mol} \cdot \mathrm{L}^{-1}\right)$ in Britton-Robinson buffer solutions $\left(0.1 \mathrm{~mol} \cdot \mathrm{L}^{-1}\right)$. $[\mathrm{CTABr}]=4.0 \times 10^{-5} \mathrm{~mol} \cdot \mathrm{L}^{-1}$ and Scan rate, $0.1 \mathrm{~V} \cdot \mathrm{s}^{-1}$.

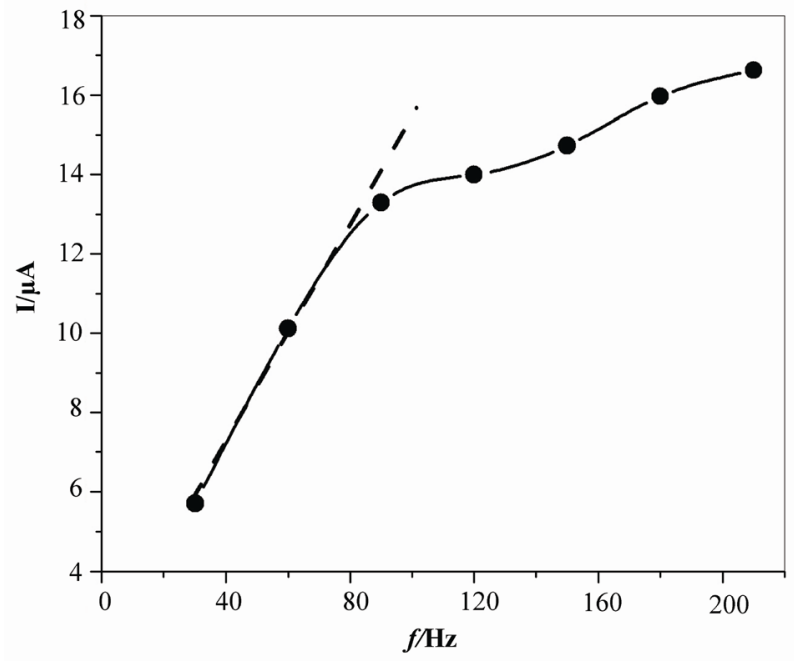

Figure 5. Dependence of the current peak on frequency at $20 \mathrm{mV}$ as amplitude value for experiments carried out under the following conditions: $[\mathrm{CTABr}]=4.0 \times 10^{-5} \mathrm{~mol} \cdot \mathrm{L}^{-1}$, benzophenone-3 $\left(1.0 \times 10^{-4} \mathrm{~mol} \cdot \mathrm{L}^{-1}\right)$ in Britton-Robinson buffer solution (pH 6) and $E_{s}=\mathbf{2} \mathbf{~ m V}$.

lyte on the reduction of BENZO in the presence of $\mathrm{CTABr}$ was studied in the $\mathrm{pH}$ range of 2 - 10 by using $\mathrm{CV}$. These experiments showed that the analytical signal obtained had a significant increase between pH 2 and 6 (Figure 4) and that to higher $\mathrm{pH}$ values the peak current decreases slightly up to $\mathrm{pH} 10$. Quantitatively, data on the response of peak current showed the best values with neutral solutions. This finding led to the choice of Britton-Robinson buffer at $\mathrm{pH} 6$ and $\mathrm{CTABr}\left(4.0 \times 10^{-5}\right.$ $\mathrm{mol} \cdot \mathrm{L}^{-1}$ ) as electrolyte for the analytical determinations.

It is also observed that with increasing $\mathrm{pH}$ of electrolyte, there is a shift of peak potential to more negative values, indicating that a chemical reaction (proton transfer reaction) precedes the process that occurs at the electrode surface [52].

\subsection{Optimization of SWV Parameters}

Several experimental parameters related to the squarewave potential scan, such as frequency $(f)$ and amplitude $\left(E_{s w}\right)$, were studied and optimized to provide maximal current peak $\left(I_{p}\right)$ and repeatability. Thus, the amplitude and frequency of SWV for the standard solution of BENZO $\left(1 \times 10^{-4} \mathrm{~mol} \cdot \mathrm{L}^{-1}\right)$ in B-R buffer solution pH 6 with CTABr were analyzed. SWV amplitude was evaluated using $100 \mathrm{~Hz}$ as frequency value and $2 \mathrm{mV}$ as scan increment. The maximum current peak at amplitude was obtained in approximately $20 \mathrm{mV}$. Likewise, Figure 5 reveals that the frequency exhibits linear behavior when $I_{p}$ does not exceed $90 \mathrm{~Hz}$, whereas for values higher than $120 \mathrm{~Hz}$ no contribution can be observed in the electroanalytical response. Linear behavior of frequency as a function of Ip is characteristic of an electrochemical irreversible process [53,54]. The solid lines presented in Figure 5 show the deviations of the linearity between $I_{p}$ vs frequency.

\subsection{Analytical Application}

The electroanalytical determination of BENZO was performed using the maximal values of peak current as a function of amplitude and the frequency values. In this case, these conditions are interrelated and optimal peak current oxidation of BENZO was obtained on BDD electrodes using $90 \mathrm{~Hz}$ and $20 \mathrm{mV}$ vs $\mathrm{Ag} / \mathrm{AgCl}$ as SWV frequency and amplitude, respectively.

With these optimized voltammetric parameters, an electroanalytical methodology were developed for determination of BENZO in pharmaceutical preparations. The square-wave voltammograms of the standard solutions as a function of BENZO concentration in aqueous solution $\mathrm{pH} 6$ (B-R buffer) in presence of CTABr are 
shown in Figure 6(a). The calibration plot yielded a straight line $(r=0.998, n=3)$ for BENZO (Figure 6(b)). Linear regression analysis of current $(\mu \mathrm{A})$ versus concentration $\left(\mathrm{mol} \cdot \mathrm{L}^{-1}\right)$ profiles showed a reasonable linearity from $1.5 \times 10^{-5}$ to $1.95 \times 10^{-4} \mathrm{~mol} \cdot \mathrm{L}^{-1}$ on the BDD electrode, as shown in the inset of Figure 6.

The determination (LD) and quantification (LQ) limits for BENZO were obtained in aqueous solutions (B-R buffer, $\mathrm{pH}$ 6) using the procedure recommended by IUPAC [55-57]. Thus, the standard deviation of the mean value of currents $\left(S_{B}\right)$ measured at the BENZO reduction potential for 10 voltammograms of the blank solution in different samples was used in conjunction with the slope of the straight line $(b)$ of the analytical curves (Figure 6(b)) and Equation 1 and 2:

$$
\begin{gathered}
L D=\frac{3 S_{B}}{b} \\
L Q=\frac{10 S_{B}}{b}
\end{gathered}
$$

The detection and quantification limits were obtained for five determinations of BENZO in pure water using BDD electrodes and SWV as the analytic technique. The results of the linear regression of the analytic curve and detection and quantification limits are presented in Table 1. The SWV method was applied to determine the BENZO content in commercial sunscreen. Determination of BENZO content in the preparation was performed by using the standard addition method. Each sample of cosmetic was treated as described in experimental section.

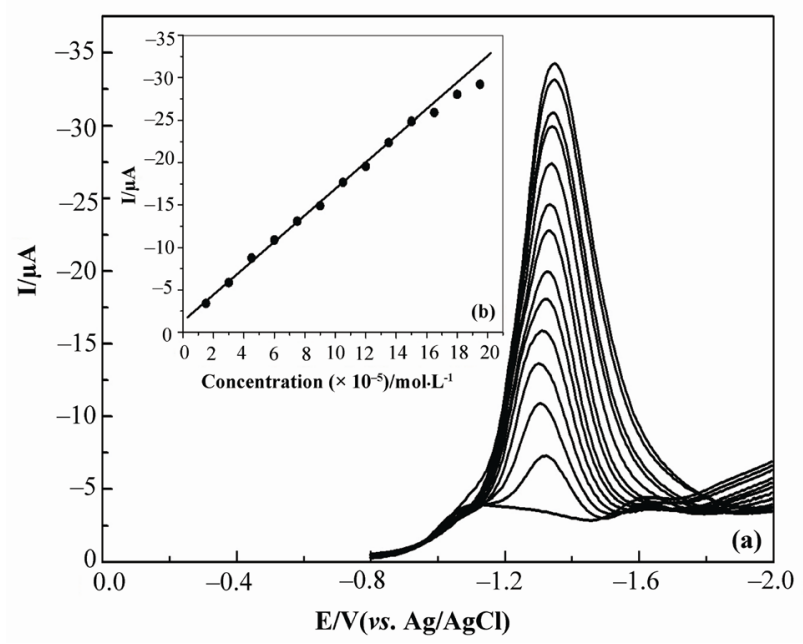

Figure 6. (a) Square-wave voltammetry responses of a BDD electrode for different benzophenone- 3 concentrations in Britton-Robinson buffer solution (pH 6); (b) Linear dependence of the peak current on benzophenone- 3 concentration. $[\mathrm{CTABr}]=4.0 \times 10^{-5} \mathrm{~mol} \cdot \mathrm{L}^{-1}, f=90 \mathrm{~Hz}, a=$
$20 \mathrm{mV}, E_{s}=2 \mathrm{mV}$.

Table 1. Result of the linear regression of the analytic curve and detection and quantification limits obtained for benzophenone-3 in medium of B-R buffer pH 6.

\begin{tabular}{cccccc}
\hline Sample & $\begin{array}{c}\text { Intercept } \\
(\mu \mathrm{A})\end{array}$ & $\begin{array}{c}\text { Slope } \\
\left(\mathrm{mA} / \mathrm{mol} \cdot \mathrm{L}^{-1}\right)\end{array}$ & $\mathrm{Sb}(\mu \mathrm{A}) \begin{array}{c}\mathrm{DL}\left(\times 10^{-7}\right. \\
\left.\mathrm{mol} \cdot \mathrm{L}^{-1}\right)\end{array}$ & $\begin{array}{c}\mathrm{QL}\left(\times 10^{-7}\right. \\
\left.\mathrm{mol} \cdot \mathrm{L}^{-1}\right)\end{array}$ \\
\hline $\begin{array}{c}\text { Benzo- } \\
\text { phenone }\end{array}$ & $1.20 \pm 0.45$ & $\begin{array}{c}1.48 \times 10^{2} \pm \\
18.5\end{array}$ & 0.007 & $1.37 \pm 0.12$ & $4.54 \pm 0.4$ \\
\hline
\end{tabular}

All measurements were performed in triplicate. The recovery efficiencies $(\% R)$ for the systems under investtigation were calculated using Equation 3 , where the "found" value refers to the concentration obtained by extrapolation of the analytical curve in the corresponding standard solution of BENZO.

$$
\% R=100 \frac{[\text { Benzophenone- } 3] \text { found }}{[\text { Benzophenone- } 3] \text { added }}
$$

The pharmaceutical preparations analyzed were sunscreen containing BENZO (5\% w/w). In Figure 7 it can be observed that the voltammetric behavior of the BENZO present in the pharmaceutical preparation is similar to that obtained with a standard solution (Figure 6(a)).

No influence of others agents content in sunscreen such as octyl metoxycinammate, propyleneglycol or 4methylbenzilidine camphor on the voltammetric response was thus observed in the interest potential range. The recoveries of known amounts of BENZO contained in pharmaceutical preparations (Table 2) ranged from $97.2 \%$ to $98.1 \%$.

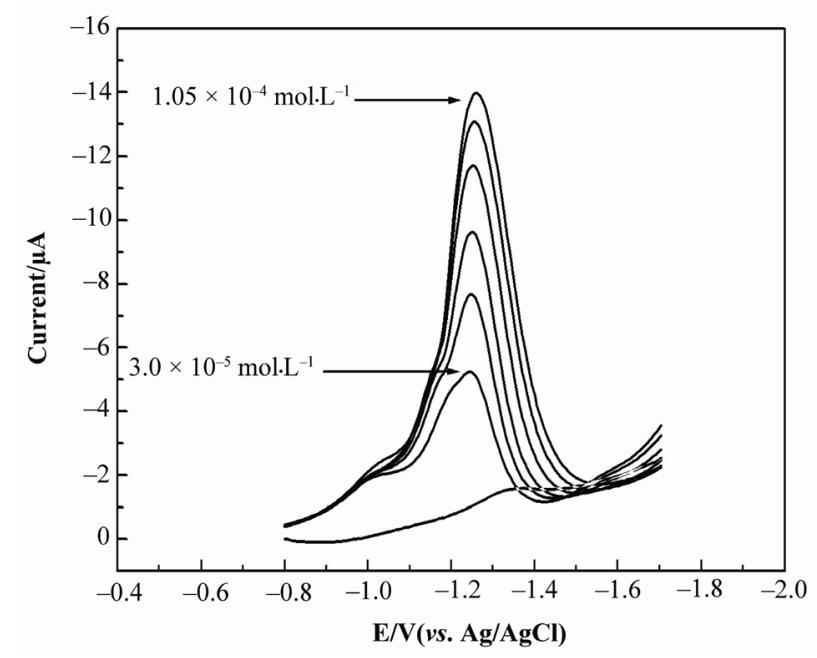

Figure 7. Square-wave voltammograms profiles of benzophenone- 3 contained in a commercial pharmaceutical preparation in Britton-Robinson buffer solution (pH 6). $[\mathrm{CTABr}]=4.0 \times 10^{-5} \mathrm{~mol} \cdot \mathrm{L}^{-1}, f=90 \mathrm{~Hz}, a=20 \mathrm{mV}$, 


$$
E_{s}=2 \mathrm{mV} \text {. }
$$

Table 2. Recoveries of benzophenone-3 samples in commercial cosmetic preparations (nominal conc. $5.0 \% \mathrm{w} / \mathrm{w}$ ) using square wave voltammetry experiments carried out using the following conditions: $f=90 \mathrm{~Hz}, a=20 \mathrm{mV}$ and $E_{s}=2 \mathrm{mV}(n=3)$.

\begin{tabular}{ccccc}
\hline $\begin{array}{c}\text { Sunblock } \\
\text { Lotion }\end{array}$ & $\begin{array}{c}\text { Added (mol· } \mathrm{L}^{-1} \\
\text { benzophenone-3) }\end{array}$ & $\begin{array}{c}\text { Found (mol· } \mathrm{L}^{-1} \\
\text { benzophenone-3) }\end{array}$ & Recovery (\%)R.S.D (\%) \\
\hline A & $1.00 \times 10^{-5}$ & $9.81 \times 10^{-6}$ & 98.1 & 0.8 \\
B & $1.00 \times 10^{-5}$ & $9.72 \times 10^{-6}$ & 97.2 & 1.1 \\
C & $1.0 \times 10^{-5}$ & $9.78 \times 10^{-6}$ & 97.5 & 0.9 \\
\hline
\end{tabular}

\section{Conclusions}

In this investigation, BENZO was found to provide a reductive peak when cyclic and square-wave voltammetry experiments where conducted using BDD electrodes. Based on these experiments, an electroanalytical method for the determination of BENZO in water and commercial sunscreen was developed. The electrochemical responses of pharmaceutical preparations were identical to those of standard BENZO and no influence of others agents content in sunscreen on the voltammetric responses was observed. BENZO recoveries values ranged from $97.2 \%$ to $98.1 \%$ demonstrate the elevated efficiency of the methodology. Consequently, given it's easily of use, high sensitivity, and brevity, the method proposed can be successfully used to determine trace amounts of BENZO in several commercial products.

\section{Acknowledgements}

The authors thank the Brazilian Research Funding Institutions CNPq, Capes, Fundect and Fapemig for financial support.

\section{References}

[1] H. Gonzalez, A. Abrot, O. Larko and A. M. Wennberg, "Percutaneous Absorption of the Sunscreen Benzophenone-3 after Repeated Whole-Body Applications, with and without Ultraviolet Irradiation," British Journal of Dermatology, Vol. 154, No. 2, 2006, pp .337-340.

[2] T. Suzuki, S. Kitamura, R. Khota, K. Sugihara, N. Fujimoto and S. Ohta, "Estrogenic and Antiandrogenic Activities of 17 Benzophenone Derivatives Used as UV Stabilizers and Sunscreens," Toxicology and Applied Pharmacology, Vol. 203, No. 1, 2005, pp. 9-17. doi:10.1016/j.taap.2004.07.005

[3] C. G. Daughton, "Environmental Stewardship and Drugs as Pollutants,” Lancet, Vol. 360, No. 9339, 2002, pp. 1035-1036. doi:10.1016/S0140-6736(02)11176-7
[4] M. E. Balmer, H. R. Buser, M. D. Muller and T. Poiger, "Occurrence of Some Organic UV Filters in Wastewater, in Surface Waters, and in Fish from Swiss Lakes," Environmental Science \& Technology, Vol. 39, No. 4, 2005, pp. 953-962. doi:10.1021/es040055r

[5] G. A. Loraine and M. E. Pettigrove, "Seasonal Variations in Concentrations of Pharmaceuticals and Personal Care Products in Drinking Water and Reclaimed Wastewater in Southern California," Environmental Science \& Technology, Vol. 40, No. 3, 2006, pp. 687-695. doi:10.1021/es051380x

[6] S. C. Rastogi and G. H. Jensen, "Identification of UV Filters in Sunscreen Products by High-Performance Liquid Chromatography-Diode Array Detection,” Journal of Chromatography A, Vol. 828, No. 1-2, 1998, pp. 311-316. doi:10.1016/S0021-9673(98)00784-5

[7] V. Vanquerp, C. Rodriguez, C. Coiffard, L. J. M. Coiffard and Y. D. Roeck-Holtzhauer, "High-Performance Liquid Chromatographic Method for the Comparison of the Photostability of Five Sunscreen Agents," Journal of Chromatography A, Vol. 832, No. 1-2, 1999, pp. 273-277. doi:10.1016/S0021-9673(98)00928-5

[8] A. Chisvert, M. C. Pascual-Marti and A. Salvador, "Determination of UV-Filters in Sunscreens by HPLC," Fresenius Journal of Analytical Chemistry, Vol. 369, No. 7-8, 2001, pp. 638-641. doi:10.1007/s002160100701

[9] T. Felix, B. J. Hall and J. S. Brodbelt, "Determination of Benzophenone-3 and Metabolites in Water and Human Urine by Solid-Phase Microextraction and Quadrupole Ion Trap GC-MS,” Analytica Chimica Acta, Vol. 371, No. 2-3, 1998, pp. 195-203. doi:10.1016/S0003-2670(98)00293-1

[10] V. Lorena, C. Alberto, C. Antonio, P. Elefteria, L. Alexei, A. Fernando, J. Karen, A. H. James and M. Frank, "Chemically Surface-Modified Carbon Nanoparticle Carrier for Phenolic Pollutants: Extraction and Electrochemical Determination of Benzophenone-3 and Triclosan,” Analytica Chimica Acta, Vol. 616, No. 1, 2008, pp. 28-35. doi:10.1016/j.aca.2008.04.011

[11] A. O. Razak, A. A. Gazy and A. M. Wahbi, "Polarographic Determination of Phenytoin and Benzophenone (as Impurity) in Pharmaceutical Preparations," Journal Pharmaceutical and Biomedical Analysis, Vol. 28, No. 3-4, 2002, pp. 613-619. doi:10.1016/S0731-7085(01)00669-0

[12] J. C. Cardoso, B. M. L. Armondes, J. B. G. Júnior and V. S. Ferreira, "Simultaneous Electrochemical Determination of Three Sunscreens Using Cetyltrimethylammonium Bromide," Colloids and Surfaces B: Biointerfaces, Vol. 63, No. 1, 2008, pp. 34-40. doi:10.1016/j.colsurfb.2007.11.001

[13] A. J. Wain, J. D. Wadhawan and R. G. Compton, "Electrochemical Studies of Vitamin K1 Microdroplets: Electrocatalytic Hydrogen Evolution," Chemical Physics And Physical Chemistry, Vol. 4, No. 9, 2003, pp. 974-982.

[14] J. M. Gong and X. Q. Lin, "Electrochemical Determination of Serotonin and the Competitive Adsorption with Dopamine at 5,5-Ditetradecyl-2-(2-trimethylammonioethyl)-1,3-dioxane Bromide Lipid Film Modified by Glassy 
Carbon Electrode,” Anaytica Sciences, Vol. 20, No. 6, 2004, pp. 905-909. doi:10.2116/analsci.20.905

[15] H. B. Suffredini, S. A. S. Machado and L. A. Avaca, "The Water Decomposition Reaction on Boron-Doped Diamond Electrode,” Journal Brazilian Chemical Society, Vol. 15, No. 1, 2004, pp. 16-21. doi:10.1590/S0103-50532004000100004

[16] R. Bellagamba, P. A. Michaud, C. Comninellis and N. Vatistas, "Electro-Combustion of Polyacrylates with BoronDoped Diamond Anodes," Electrochemistry Commuication, Vol. 4, No. 2, 2002, pp. 171-176. doi:10.1016/S1388-2481(01)00302-2

[17] J. S. Foord and C. H. Goeting, "Electrochemically Controlled Modification of CVD Diamond Surfaces," Diamond and Related Materials, Vol. 13, No. 4-8, 2004, pp. 1054-1058. doi:10.1016/j.diamond.2003.12.016

[18] M. C. Granger and G. M. Swain, “The Influence of Surface Interactions on the Reversibility of Ferri/Ferrocyanide at Boron-Doped Diamond Thin-Film Electrodes," Journal of the Electrochemical Society, Vol. 146, No. 12, 1999, pp. 4551-4558. doi:10.1149/1.1392673

[19] I. Duo, C. Lévy-Clément, A. Fujishima and C. Comninellis, "Electron Transfer Kinetics on Boron-Doped Diamond Part I: Influence of Anodic Treatment," Journal of Applied Electrochemistry, Vol. 34, No. 9, 2004, pp. 935943. doi:10.1023/B:JACH.0000040525.76264.16

[20] H. B. Suffredini, V. A. Pedrosa, L. Codognoto, S. A. S. Machado, R. C. Rocha-Filho and L. A. Avaca, "Enhanced Electrochemical Response of Boron-Doped Diamond Electrodes Brought on by a Cathodic Surface Pre-Treatment,” Electrochimica Acta, Vol. 49, No. 22-23, 2004, pp. 4021-4026. doi:10.1016/j.electacta.2004.01.082

[21] G. R. Salazar-Banda, L. S. Andrade, P. A. P. Nascente, P. S. Pizani, R. C. Rocha-Filho and L. A. Avaca, "On the Changing Electrochemical Behaviour of Boron-Doped Diamond Surfaces with Time after Cathodic Pre-Treatments," Electrochimica Acta, Vol. 51, No. 22, 2006, pp. 4612-4619. doi:10.1016/j.electacta.2005.12.039

[22] M. S. Saha, T. Furuta and Y. Nishiki, "Conversion of Carbon Dioxide to Peroxycarbonate at Boron-Doped Diamond Electrode," Electrochemistry Communication, Vol. 6, No. 2, 2004, pp. 201-204.

doi:10.1016/j.elecom.2003.11.014

[23] J. Iniesta, P. A. Michaud, M. Panizza and C. Comninellis, "Electrochemical Oxidation of 3-Methylpyridine at a Boron-Doped Diamond Electrode: Application to Electroorganic Synthesis and Wastewater Treatment," Electrochemistry Communication, Vol. 3, No. 7, 2001, pp. 346- 351. doi:10.1016/S1388-2481(01)00174-6

[24] J. W. Strojek, M. C. Granger, T. Dallas, M. W. Holtz and G. M. Swain, "Enhanced Signal-to-Background Ratios in Voltammetric Measurements Made at Diamond ThinFilm Electrochemical Interfaces," Analytical Chemistry, Vol. 68, No. 13, 1996, pp. 2031-2037. doi:10.1021/ac9506847

[25] M. Hupert, A. Muck, J. Wang, J. Stotter, Z. Cvackova, S. Haymond, Y. Show and G. M. Swain, "Conductive Diamond Thin-Films in Electrochemistry," Diamond and
Related Materials, Vol. 12, No. 10-11, 2003, pp. 19401949. doi:10.1016/S0925-9635(03)00260-7

[26] Y. Yano, D. A. Tryk, K. Hashimoto and A. Fujishima, "Electrochemical Behavior of Highly Conductive BoronDoped Diamond Electrodes for Oxygen Reduction in Alkaline Solution," Journal of the Electrochemical Society, Vol. 145, No. 6, 1998, pp. 1870-1876. doi:10.1149/1.1838569

[27] N. Vinokur, B. Miller, Y. Avyigal and R. Kalisk, "Electrochemical Behavior of Boron-Doped Diamond Electrodes," Journal of the Electrochemical Society, Vol. 143, No. 10, 1996, pp. L238-L240. doi:10.1149/1.1837157

[28] T. N. Rao, Y. Yagi, T. Miwa, D. A. Tryk and A. Fujishima, "Electrochemical Oxidation of NADH at Highly Boron-Doped Diamond Electrodes,” Analytical Chemistry, Vol. 71, No. 13, 1999, pp. 2506-2511. doi:10.1021/ac981376m

[29] E. Popa, H. Notsu, T. Miwa, D. A. Tryk and A. Fujishima, "Selective Electrochemical Detection of Dopamine in the Presence of Ascorbic Acid at Anodized Diamond Thin Film Electrodes," Electrochemistry and Solid-State Letters, Vol. 2, No. 1, 1999, pp. 49-51. doi:10.1149/1.1390730

[30] J. Iniesta, P. A. Michaud, M. Panizza, C. Cerisola, A. Aldaz and C. Comniniellis, "Electrochemical Oxidation of Phenol at Boron-Doped Diamond Electrode," Electrochimica Acta, Vol. 46, No. 23, 2001, pp. 3573-3578. doi:10.1016/S0013-4686(01)00630-2

[31] M. C. Granger, J. S. Xu, J.W. Strojek and G. M. Swain, "Polycrystalline Diamond Electrodes: Basic Properties and Applications as Amperometric Detectors in Flow Injection Analysis and Liquid Chromatography,” Analytica Chimica Acta, Vol. 397, No. 1-3, 1999, pp. 145-161. doi:10.1016/S0003-2670(99)00400-6

[32] V. A. Pedrosa, L. Codognoto and L. A. Avaca, "Electroanalytical Determination of 4-Nitrophenol by Square Wave Voltammetry on Diamond Electrodes," Journal of the Brazilian Chemical Society, Vol. 14, No. 4, 2003, pp. 530-535. doi:10.1590/S0103-50532003000400007

[33] V. A. Pedrosa, L. Codognoto and L. A. Avaca, "Is the Boron-Doped Diamond Electrode a Suitable Substitute for Mercury in Pesticide Analyses? A Comparative Study of 4-Nitrophenol Quantification in Pure and Natural Waters," Journal of Electroanalytical Chemistry, Vol. 573, 2004, pp. 11-18.

[34] V. A. Pedrosa, H. B. Suffredini, L. Codognoto, S. T. Tanimoto, S. A. S. Machado and L. A. Avaca, "Carbon Surfaces for Electrochemical Applications. A Comparative Study,” Analytical Letters, Vol. 38, 2005, pp. 11151125.

[35] L. Codognoto, S. A. S. Machado and L. A. Avaca, "Square Wave Voltammetry on Boron-doped Diamond Electrodes for Analytical Determination," Diamond and Related Materials, Vol. 11, No. 9, 2002. pp. 1670-1675. doi:10.1016/S0925-9635(02)00134-6

[36] G. W. Muna, N. Tasheva and G. M. Swain "Electro-Oxidation and Amperometric Detection of Chlorinated Phenols at Boron-Doped Diamond Electrodes: A Compari- 
son of Microcrystalline and Nanocrystalline Thin Films,” Environmental Science \& Technology, Vol. 38, No. 13, 2004, pp. 3674-3682. doi:10.1021/es034656e

[37] C. E. Banks, M. E. Hyde, P. Tomcik, R. Jacobs and R. G. Comptom, "Cadmium Detection via Boron-Doped Diamond Electrodes: Surfactant Inhibited Stripping Voltammetry,” Talanta, Vol. 62, No. 2, 2004, pp.279-286. doi:10.1016/j.talanta.2003.07.008

[38] J. Iniesta, P. A. Michaud, M. Panizza and C. Comninellis, "Electrochemical Oxidation of 3-Methylpyridine at a Boron-Doped Diamond Electrode: Application to Electroorganic Synthesis and Wastewater Treatment," Electrochemistry Communication, Vol. 3, No. 7, 2001, pp. 346-351. doi:10.1016/S1388-2481(01)00174-6

[39] P. A. Michaud, E. Mahé, W. Haenni, A. Perret and C. Comninellis, "Preparation of Peroxodisulfuric Acid Using Boron-Doped Diamond Thin Film Electrode," Electrochemistry and Solid-State Letters, Vol. 3, No. 2, 2000, pp. 77-79. doi:10.1149/1.1390963

[40] R. T. S. Oliveira, G. R. Salazar-Banda, M. C. Santos, M. L. Calegaro, D. W. Miwa, S. A. S. Machado and L. A. Avaca, "Electrochemical Oxidation of Benzene on Boron-Doped Diamond Electrodes," Chemosphere, Vol. 66, No. 11, 2007, pp. 2152-2158. doi:10.1016/j.chemosphere.2006.09.024

[41] E. Brillas, B. Boye, I. Sires, J. A. Garrido, R. M. Rodriguez, C. Arias, P. L. Cabot and C. Comninellis, "Electrochemical Destruction of Chlorophenoxy Herbicides by Anodic Oxidation and Electro-Fenton Using a BoronDoped Diamond Electrode,” Electrochimica Acta, Vol. 49, No. 25, 2004, pp. 4487-4496. doi:10.1016/j.electacta.2004.05.006

[42] J. F. Zhi, H. B. Wang, T. Nakashima, T. N. Rao and A. Fujishima, "Electrochemical Incineration of Organic Pollutants on Boron-Doped Diamond Electrode. Evidence for Direct Electrochemical Oxidation Pathway,” Journal of Physical Chemistry B, Vol. 107, No. 48, 2003, pp. 13389-13395. doi:10.1021/jp030279g

[43] R. Bellagamba, P. A. Michaud, C. Comninellis and N. Vatistas, "Electro-Combustion of Polyacrylates with Boron-Doped Diamond Anodes," Electrochemistry Communication, Vol. 4, No. 2, 2002, pp. 171-176. doi:10.1016/S1388-2481(01)00302-2

[44] F. Montilla, E. Morallon, I. Duo, C. Comninellis and J. L. Vazquez, "Platinum Particles Deposited on Synthetic Boron-Doped Diamond Surfaces. Application to Methanol Oxidation,” Electrochimica Acta, Vol. 48, No. 25-26, 2003, pp. 3891-3897. doi:10.1016/S0013-4686(03)00526-7

[45] G. R. Salazar-Banda, H. B. Suffredini and L. A. Avaca, "Improved Stability of PtOx Sol-Gel Modified Diamond Electrodes Covered with a Nafion Film," Journal of the Brazilian Chemical Society, Vol. 16, No. 5, 2005, pp. 903-906. doi:10.1590/S0103-50532005000600003

[46] H. B. Suffredini, G.R. Salazar-Banda, S. T. Tanimoto, M. L. Calegaro, S. A. S. Machado and L. A. Avaca, “AFM Studies and Electrochemical Characterization of BoronDoped Diamond Surfaces Modified with Metal Oxides by the Sol-Gel Method,” Journal of the Brazilian Chemical Society, Vol. 17, No. 2, 2006, pp. 257-264. doi:10.1590/S0103-50532006000200007

[47] C. Terashima, T. N. Rao, B. V. Sarada, Y. Kubota and A. Fujishima, "Direct Electrochemical Oxidation of Disulfides at Anodically Pretreated Boron-Doped Diamond Electrodes,” Analytical Chemistry, Vol. 75, No. 7, 2003, pp. 1564-1572. doi:10.1021/ac020583q

[48] T. N. Rao, T. A. Ivandini, C. Terashima, B. V. Sarada and A. Fujishima, "Applications of Bare and Modified Diamond Electrodes in Electroanalysis,” New Diamond Frontier Carbon Technology, Vol. 13, 2003, pp.79-88.

[49] R. T. S. Oliveira, G. R. Salazar-Banda, S. C. Oliveira, V. S. Ferreira and L. A. Avaca, "Electroanalytical Determination of Lidocaine in Pharmaceutical Preparations Using Boron- Doped Diamond Electrodes,” Electroanalysis, Vol. 19, No. 11, 2007, pp. 1189-1194. doi:10.1002/elan.200603840

[50] R. T. S. Oliveira, G. R. Salazar-Banda, S. A. S. Machado and L. A. Avaca, "Electroanalytical Determination of NNitrosamines in Aqueous Solution Using a Boron-Doped Diamond Electrode," Electroanalysis, Vol. 20, No. 4, 2008, pp. 396- 401. doi:10.1002/elan.200704055

[51] G. Pastor-Moreno and D. J. Riley, "The Influence of Surface Preparation on the Electrochemistry of Boron-Doped Diamond: A Study of the Reduction of 1,4-Benzoquinone in Acetonitrile," Electrochemistry Communication, Vol. 4, No. 2, 2002, pp. 218-221. doi:10.1002/elan.200704055

[52] A. Arranz, L. Dolara, S. F. Betõno, J. M. Moreda, A. Cid and J. F. Arranz, "Electroanalytical Study and Square Wave Voltammetric Techniques for the Determination of $\beta$-Blocker Timolol at the Mercury Electrode,” Analytica Chimica Acta, Vol. 389, No. 1-3, 1999, pp. 225-232. doi:10.1016/S0003-2670(99)00214-7

[53] M. Lovrić, K. Šebojka and W. Murray, “Adsorption Effects in Square-Wave Voltammetry of Totally Irreversible Redox Reactions,” Electrochimica Acta, Vol. 33, No. 6, 1988, pp. 739-744. doi:10.1016/S0013-4686(98)80002-9

[54] M. Lovrić and K. Šebojka, "Square-Wave Voltammetry of an Adsorbed Reactant," Journal of Electronalytical Chemistry and Interfacial Electrochemistry, Vol. 248, No. 2, 1988, pp. 239-253. doi:10.1016/0022-0728(88)85089-7

[55] R. Q. Thompson, M. Porter, C. Stuver, H. B. Halsall, W. R. Heineman, E. Buckley and M. R. Smyth, "Zeptomole Detection Limit for Alkaline Phosphatase Using 4-Aminophenyl-Phosphate, Amperometric Detection, and an Optimal Buffer System,” Analytica Chimica Acta, Vol. 271, No. 2, 1993, pp. 223-229. doi:10.1016/0003-2670(93)80049-Q

[56] L. A. Currie, "International Recommendations Offered on Analytical Detection and Quantification Concepts and Nomenclature,” Analytica Chimica Acta, Vol. 391, No. 2, 1999, p. 103. doi:10.1016/S0003-2670(99)00103-8

[57] J. Mocak, A. M. Bond, S. Mitchell and G. Scollary, “A Statistical Overview of Standard (IUPAC and ACS) and New Procedures for Determining the Limits of Detection and Quantification: Application to Voltammetric and 
Stripping Techniques,” Pure and Applied Chemistry, Vol. 69, No. 2, 1997, pp. 297-328. 